Paper for presentation and publication at WEFTEC 2006 -

Water Environment Federation $79^{\text {th }}$ Annual Technical Exhibition \& Conference

Oct 21-25, 2006, Dallas, TX, USA

\title{
LINKING DATA, PUBLIC OUTREACH AND EDUCATION: A LOCAL AND REGIONAL COLLABORATIVE - LAKESUPERIORSTREAMS.ORG
}

\author{
Marnie Lonsdale , Todd Carlson ${ }^{*}$, Richard Axler ${ }^{* *}$, Cynthia Hagley ${ }^{* * *}$, George Host ${ }^{* *}$, \\ Jane Reed $^{* *}$, Jesse Schomberg ${ }^{* * *}$, Norm Will ${ }^{* *}$, Elaine Ruzycki ${ }^{* *}$, Jerry Henneck ${ }^{* *}$, \\ *City of Duluth, 520 Garfield Ave, Duluth MN 55802 \\ ** Natural Resources Research Institute, University of Minnesota-Duluth, Duluth, MN 55811 \\ ${ }^{* * *}$ Minnesota Sea Grant College, University of Minnesota-Duluth, Duluth, MN 55812
}

\begin{abstract}
The City of Duluth, the University of Minnesota-Duluth (Natural Resources Research Institute and Minnesota Sea Grant) and other regional partners collaborated to develop Lakesuperiorstreams.org, a website that utilizes real time data (temperature, flow, precipitation, turbidity, specific conductivity) in an easy to understand animated graphical format to educate the public about (1) how streams function, and (2) the impacts of human activities on water quality, habitat, and aquatic organisms. In support of the data, the website provides a comprehensive library of information on stream parameters and information on local streams and surface water issues. It covers land use impacts on streams and positive approaches to protecting water quality. For example, a site design tool kit provides information and examples of approaches to building and maintaining homes and businesses while reducing stormwater impacts. The website also serves as a repository for regionally relevant school curricula for K-12 schools and colleges. The website has been the catalyst that has brought together regional agencies and communities, who have established the Regional Stormwater Protection Team (RSPT), designed to develop one voice for surface water education and technical assistance for communities at the head of Lake Superior.
\end{abstract}

\section{KEYWORDS}

Website, data visualization, stream, stormwater, watersheds, stream habitat, non point source pollution, stream monitoring, water quality, stream ecology

\section{INTRODUCTION}

The City of Duluth is located on the western shore of Lake Superior on a steep escarpment that rises more than $260 \mathrm{~m}$ ( $\sim 880 \mathrm{ft}$ ) above the surface of the lake and the Duluth-Superior Harbor. Forty-two named streams flow through the City and twelve are designated cold water trout streams. The streams, in most instances, appear untouched and almost unaffected by the developing urban environment, but this is changing and the streams are beginning to encounter 
problems. Despite its appearance the region is undergoing stresses from increased urbanization and tourism development. Pressure on western Lake Superior streams and near shore zones comes primarily from stormwater runoff and sanitary sewer overflows. There are also threats to public health via pathogens from sanitary system spills and storm water runoff, and from mercury-contaminated fish. Increased flows, velocity, temperature, sediments, turbidity, nutrients and organic matter all represent ecological health risks. Some streams have already been placed on the state's Impaired Waters List and will require Total Maximum Daily Load (TMDL) studies for turbidity, temperature, and/or mercury concentrations in fish tissue (MPCA 2004). The Duluth-Superior harbor at the mouth of the St. Louis River is also degraded and listed as one of the 43 Great Lakes Areas of Concern (AOC) because of serious impairments to its beneficial uses (chiefly from contaminated sediments). Stream and coastal zone degradation pose a significant social and economic impact to a region whose economy and character are tied to its pristine, natural state.

Because the region still appears virtually pristine, the approximately 150,000 residents in the metropolitan area have a limited awareness of their impact on the environment and their individual role in protecting their water assets. Local communities and environmental organizations face the challenge of delivering a "protection" message in a world where most environmental messages are restoration oriented. The lakesuperiorstreams.org website (LSS) is designed to specifically provide residents with novel data visualization tools for visually illustrating the water quality effects from human impact in the region. The site also provides a strong technical and informational component to the outreach efforts of the Regional Stormwater Protection Team (RSPT) established in 2003, in part as the result of the network formed during creation of the website.

\section{BACKGROUND AND OBJECTIVES}

The website development began in 2002 with funding provided by a U.S Environmental Protection Agency EMPACT (Environmental Monitoring for Public Access and Community Tracking) grant awarded to the City of Duluth in partnership with the University of MinnesotaDuluth (UMD) (Axler and Lonsdale 2003; Axler et al. 2004). The UMD team of scientists had previously (1997-2001) developed two innovative websites, Waterontheweb.org (WOW) and Lakeacccess.org, that used intensive, real-time data collected from water quality robots on lakes to teach basic and aquatic science and to educate lake-users about the potential effects of lawn fertilizers, stormwater runoff and other land use activities on water quality in Minneapolis, MN area urban lakes. These projects developed unique data visualization tools that allowed the user to interactively graph and animate data from a variety of lakes and rivers (Munson et al. 2003; Host et al. 2000; Peterson et al. 2002). Project leaders also created regional and national educational materials and were interested in developing a third site that concentrated on streams and stormwater runoff, and served the local community. Concurrently, the City of Duluth was developing a Surface Water Management Plan, and was in the process of preparing for federal permit requirements for National Pollution Discharge Elimination System (NPDES) Phase II Small Municipal Separate Storm Sewer System (MS4) Program. The City recognized the timeliness of the opportunity to team with the University. 
The website was originally developed to target just the streams within the municipal boundaries of Duluth and was known as duluthstreams.org. However, after the formation of the RSPT, the team recognized that the site could be an effective regional tool, leading to a change to a more inclusive site name lakesuperiorstreams.org. In support of the broader region being served by the website, it has now received additional funding through grants from Minnesota's Lake Superior Coastal Program funded through the National Oceanic and Atmospheric Administration and from the Minnesota Pollution Control Agency.

The project has the following major objectives:

1. Link real-time remote sensing of water quality in urban and rural streams and GIS technology to current and historical water quality and biological databases using advanced data visualization tools in World Wide Web and informational kiosk formats;

2. Incorporate visually engaging interpretive text, animation and videos into the website to illustrate the nature and consequences of degraded stormwater and the real cost to society;

3. Engage the public in the stormwater issue via programmatic activities such as establishing stewardship/monitoring of streams, creating and disseminating curricular materials for schools (elementary, middle and high school) and colleges (via Waterontheweb.org) through the adaptation of existing materials, creation of new materials, helping to establish school-directed stewardship and monitoring of streams and providing website support for other existing monitoring programs.

4. Facilitate public access to water-related information, including drinking water, wastewater, ground water, and stormwater and provide guidance on minimizing impacts on local water resources;

5. Support regional communities in the development of Storm Water Pollution Prevention Programs (SWPPP) as part of their National Pollution Discharge Elimination System (NPDES) Phase II Small Municipal Separate Storm Sewer System (MS4) permit program.

6. Initiate the establishment of a library of monitoring and GIS data for the sub-watersheds of Lake Superior.

7. Provide links and information on the geological, historical and biological nature of the Lake Superior shore line and the communities of the region.

8. Provide a communication link for the Regional Stormwater Protection Team, an educational and technical support group of 22 regional municipalities and agencies in Minnesota and Wisconsin.

The challenge for LSS has been to create and maintain a website that meets these objectives while remaining user-friendly, up-to-date and interesting.

\section{WEBSITE CONTENTS}

\section{Home Page}

The home page of the website has been designed to be easily understood and provide a quick guide to tools available on the website. Users may select from five main topic areas and quickly reach the tools of interest. For the frequent user, a "what's new" link goes directly to 
new information on the site. There are five main topic areas: The Streams, Lake Superior Communities, Stormwater, Citizens and Schools, and Understanding. A simple mouse click allows visitors to immediately move to their area of interest. Each area has a subdirectory of topics to assist in selection.

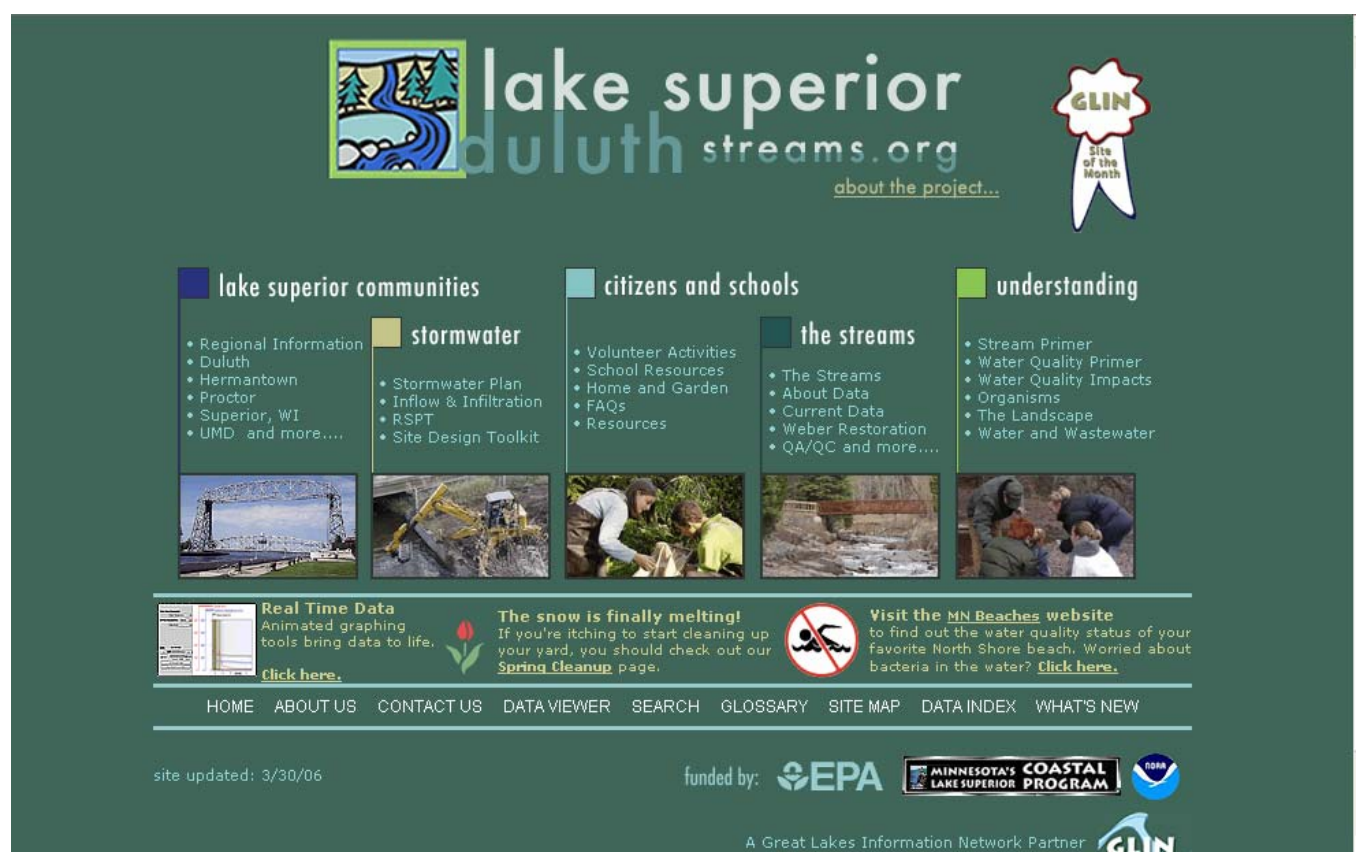

\section{The Streams - Data Visualization}

Visitors selecting the Streams section have access to real-time and ancillary data as well as information about the streams of the region. The site features a data visualization tool that allows visitors to look at near real-time data, collected via data loggers at 15 minute intervals. These data demonstrate what is occurring in regional streams throughout most of the year. The site now provides intensive data for five streams and the St. Louis River at the ship canal where it flows from the estuary into Lake Superior. Additional grant funding has allowed LSS to incorporate data from two additional non-urban streams on the north shore of Lake Superior. Data available includes stage height (water depth), flow (calculated from stage height using empirically derived rating curves), temperature, specific electrical conductivity (EC25), turbidity and precipitation. A carefully designed Quality Assurance/Quality Control (QA/QC) program (www.duluthstreams.org/streams/QA_QC.html)_was established to ensure that data accuracy is maintained.

Visitors have a variety of options for reviewing and using the data. Data can be downloaded in HTML and Excel formats. Real time data in Excel format can be easily graphed using an Excel graphing utility. Seasonal and event-based water chemistry data is also collected periodically from the sites and is available in Excel format. Data can viewed interactively online using the 2D data plotter that provides an animated graph of data over time. The graph allows the viewer to observe changes such as an increase in electrical conductivity (a good estimator of road salt) during snow melt or the rise in turbidity that can result from increased 
suspended sediment from heavy summer rainfalls. The graph also illustrates the rise in water temperature as the result of a summer storm and even the simple rise and fall of stream temperature each day. A Copy this Plot tool allows the user to view the effects of rain events on creeks in different locales in the community side by side to more dramatically illustrate the effects of varying degrees of urbanization in different streams. The window of time being examined can be varied from 12 hours to 60 days to address different types of questions.
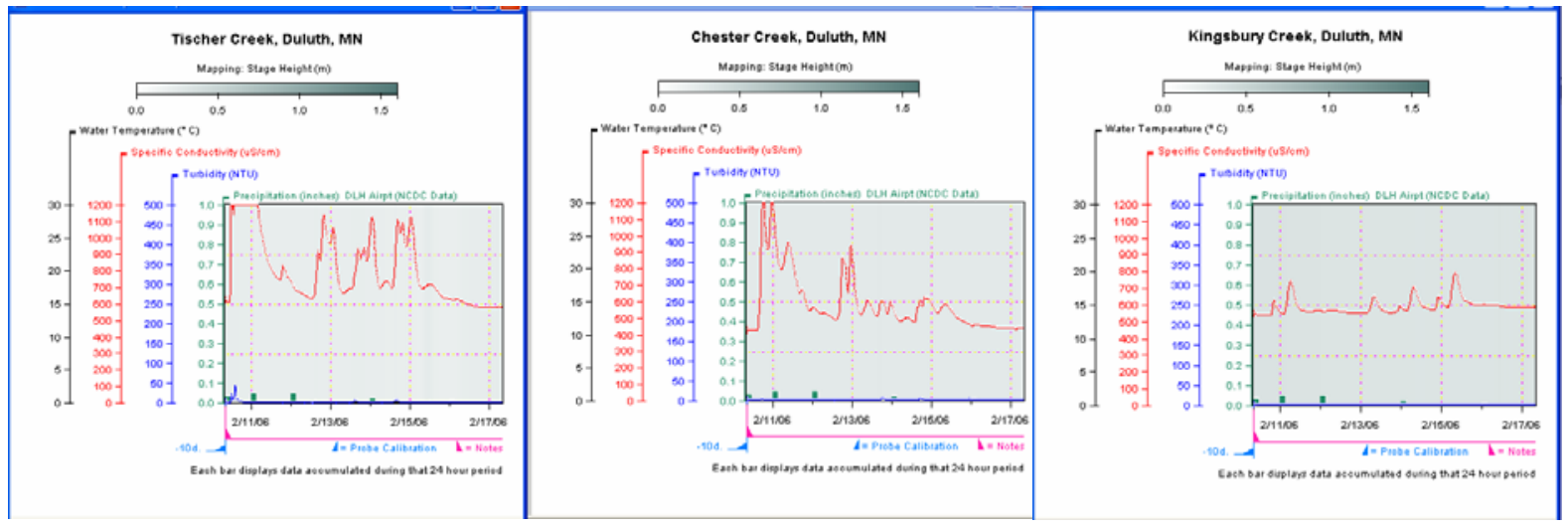

2006 February snow melt in 3 creeks

The graphic illustrations are excellent tools to help the general public, as well as educators, agency staff and scientists understand that otherwise nearly invisible changes are occurring in local creeks as the result of human activity. In one instance two summers ago, turbidity information from a creek assisted the Minnesota Pollution Control agency in tracking problems with sediment control at a construction site and in illustrating to the contractors exactly when the problem occurred and how significant the impact was to the stream.

A number of regional schools are using the site as a resource for science classes as well as a method for acquainting and involving students in utilizing graphs. One local school involved in monitoring a creek has been able to graph and compare their sampling results to the website monitoring results. By comparing data, the students develop a better understanding of how and why data can vary when collected from different sources using different sampling techniques.
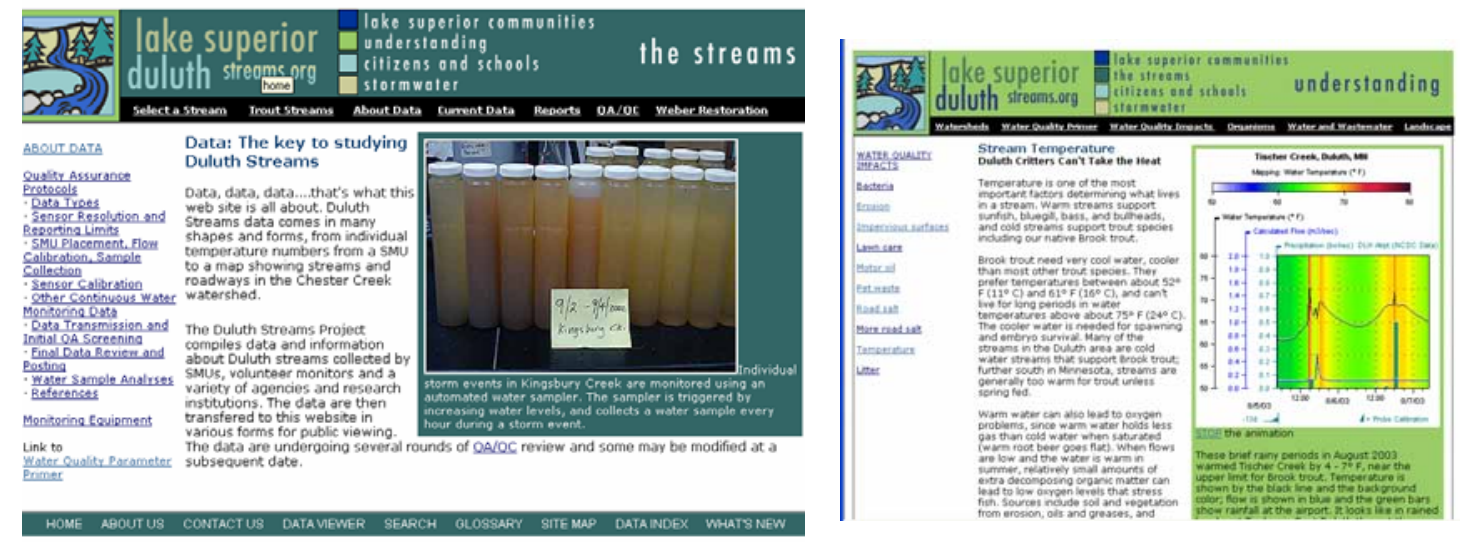
For the new user, with minimal understanding of data, the data pages link to a page "about data" within Understanding. Here, each of the parameters is explained with illustrations to allow a novice user the opportunity to understand the context for performing the measurements.

For users that want to learn more about stream watersheds, information is provided about the watershed size and land uses. Users can mouse click on regional maps in the stream section to go directly to information about a specific creek or watershed. For many creeks photographs and land use information are available. More information is being added as resources are identified. The City of Duluth has developed a series of collectable stream cards that feature the streams of the region with information on locations, trails and specific stream characteristics. The cards reference LSS for more extensive information. These cards are distributed to classes and at fairs and other activities.

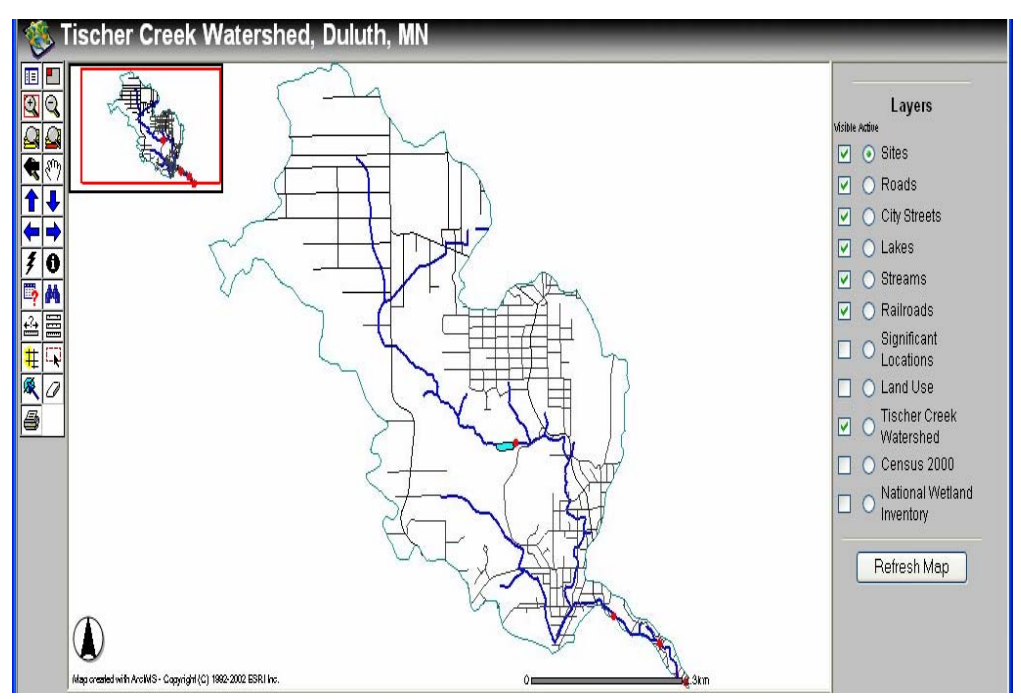

A GIS utility, Internet Map Server (IMS), allows the user to zoom in on maps of the watersheds for intensively monitored streams and at maximum zoom converts to infrared photographs with a resolution of $\sim 2-3 \mathrm{~m}$. This tool is popular with middle and high school science students. A new tool making use of on-line Google Earth software is in development.

In the archives section of Current Data, the user will find a compilation of reports and websites that are briefly annotated to indicate sources of other relevant stream data.

A new section focuses on the streams of the north shore of Lake Superior. Only limited knowledge is available about these pristine streams northeast of Duluth. The LSS team is currently compiling information and photographs to provide users with more information on the characteristics of these relatively un-impacted streams, as well as information on where to obtain additional information and how to influence environmental decision-making.

Such data is increasingly important as more tourists discover the North Shore of Lake Superior and pressure increases for development. Over the past decade or so, over 50 new lodging establishments were constructed along the north shore. Cook County increased 24\% in population from 1990-1996 (MPCA 2000). Stream communities of fish and amphibians and the invertebrates that sustain them are being adversely impacted by increased 
temperature, turbidity, suspended solids, road salts, organic matter, and nutrients (Anderson et al. 2003). Nine Superior tributaries are now on the Minnesota List of Impaired Waters, with TMDL (Total Maximum Daily Load) studies in development, chiefly for turbidity/TSS and fish-Hg. Further, these streams discharge either directly into ultra-oligotrophic Lake Superior or indirectly via the St. Louis River Estuary-Duluth Superior Harbor.

\section{Lake Superior Communities - local information}

This section provides the user with an overview of the natural and human environment in the region. Users can learn about the region's communities and recreational activities, as well as information about the region's climate, geology, and organisms (both aquatic and terrestrial). Photographs and facts about the Lake Superior and its watershed are available. The community section is a good first stopping point for visitors to the region.

Communities can use this section to highlight their activities and provide links to Storm Water Pollution Prevention Programs (SWPPPs) and other stormwater activities. For small regional townships with minimal staff and funding, LSS provides an opportunity to have information easily available to residents about local water resource issues and pollution prevention.

\section{Stormwater Management - action and compliance}

This section includes stormwater-related activities conducted by cities and other MS4 permittees in the region. It provides information on some of the key compliance issues such as information on sanitary sewer overflows and links to actions that homeowners and others can take to keep stormwater as clean as possible and to reduce runoff. The EPA NPDES Phase II Minimum Measures are described, and links to community NPDES Phase II permit submissions are available.

Activities of the Regional Stormwater Protection Team are also posted in this section. Users can view brochures, public service announcements and information about RSPT events including the watershed festival and construction workshops.

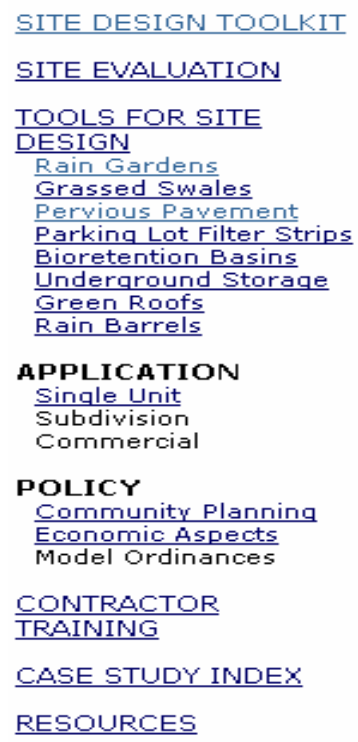

One unique feature of the Stormwater Management Section is a Site Design Toolkit. The toolkit provides planning and engineering design approaches that minimize stormwater impacts associated with water quality and hydrology (volume of water and peak flows). The toolkit includes explanations and regional examples of site development approaches that reduce the impacts of development on water quality. It discusses a cross section of the most popular tools including rain gardens, swales, pervious pavement, filter strips, bioretention basins, underground storage, green roofs and rain barrels. For each BMP, there are applications and examples, materials and installation tips and wisdom, limitations and additional resources. Where possible, regional examples and specific 
contacts are provided. The limitation section highlights problems that may reduce the effectiveness of the tools due to problems with regional characteristics including the cold climate and typically heavy, tight soils. There is also a Policy section containing information about ordinances, comprehensive planning, and economic analysis, low impact designs, and a Contractor Training section.

\section{Citizens and Schools - The role of the public}

The Citizen and Schools section provides information, resources and activities for home owners, teachers, and youth groups that want to become involved in water quality protection. Teachers can find curricula and information for school activities. The website serves as a repository for regionally relevant school curricula for K-12 schools and colleges. Students can download a scavenger hunt worksheet and go on a scavenger hunt through the website. As part of the game they can find and learn how to use many of the features of the site.

Homeowners can find information on yard care, septic systems and answers to many common questions about home and garden care. As in other sections, there are links to other reputable sources of information and to opportunities for volunteer monitoring or participation in other regional programs.

\section{Understanding - basic scientific knowledge about streams, watersheds, water cycling and water treatment in the region}

For the student completing a homework assignment, the curious resident or the planning commission member that needs information to interpret a report, this section of the site is an invaluable tool. By incorporating pictures, graphs and clearly written explanations the site provides an educational tool useful to K-12 students and their teachers, college students, contractors and consultants, decision makers, resource agencies and the general public. The explanation of the "jargon" of stream and lake monitoring parameters (flow, temperature, conductivity, turbidity, sediments, $\mathrm{pH}$, dissolved oxygen, nutrients, biochemical oxygen demand, TSS, and fecal coliforms) includes discussion of what the terms mean, why they are important, and the impacts of changing their values on the stream's organisms and on the beneficial uses of the water by society. The section links back to the real-time data, giving user immediate access to actual data applications.

The Understanding section also provides detailed information on the organisms of the stream. Visitors can learn more about the fish, aquatic plants, bacteria, algae, insects, birds, mammals and reptiles of the stream community. For each component general information and links to more detailed sites are provided. Special feature articles provide the user with a more in-depth understanding of both the scientific and practical aspects of how our society interacts with the environment. In 2005, LSS received an Environmental Leadership Award at the $4^{\text {th }}$ Annual Road Salt Symposium in St. Cloud Minnesota for the feature "How much salt is a problem". The feature presents information on why salt is used on roads in winter, ways to control salt usage, the effects of the salt on the biota of streams and links to other articles and research papers on the effects of winter road salt on surface and groundwater resources and vegetation. 


\section{WEBSITE USAGE}

LSS has become an important central resource for those that wish to study the cold water streams of the north woods. The website has been visited by users in 140 countries. Queries from users indicate that it is being used by dozens of universities and community colleges. The site has seen a steady growth in usage in its four years of operation.

\begin{tabular}{|l|}
\hline Lake Superior \\
\hline Streams.org \\
$\sim 285,000$ request/mo \\
and $\sim 65,000$ page \\
requests $/$ mo \\
\\
\end{tabular}

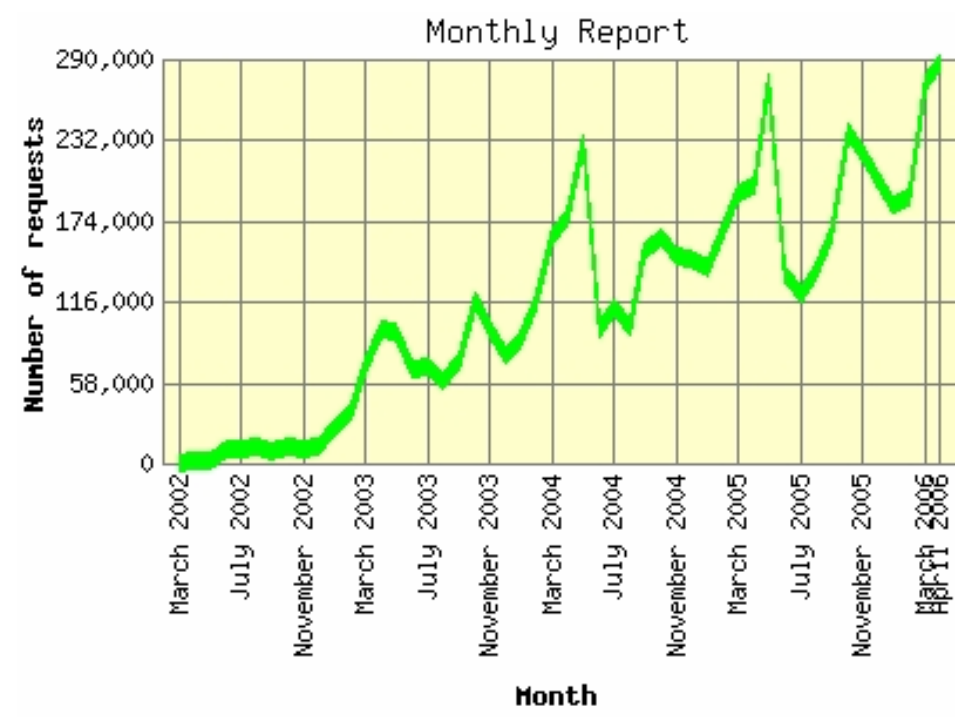

LSS has received local and national recognition including a Technical Excellence Award in recognition of "Outstanding Research in Stream and Lake Restoration, Protection and Management" from the North American Lake Management Society (NALMS 2005), selection as site of the month in December 2005 by the Great Lakes Information Network (GLIN) and the Media award from the St. Louis River Citizens Action Committee.

\section{PARTNERSHIP EFFORTS}

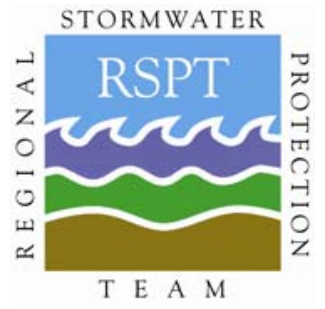

LSS was instrumental in the formation of the educational and technical support partnership, the Regional Stormwater Protection Team (RSPT). The original grant partners recognized the valuable support the website could provide for local stormwater education efforts and NPDES permit requirements. In 2002, members of the LSS team organized a workshop for MS4 communities in northern Minnesota and Wisconsin. From that original workshop, the Regional Stormwater Protection Team was formed.

RSPT now has a membership of 22 organizations from Minnesota and Wisconsin including all regional MS4s, the two largest local Universities, local/state resource and regulatory agencies, the Fond du Lac Reservation and non-profit organizations. The mission of the RSPT is: 
To protect and enhance the region's shared water resources through stormwater pollution prevention by providing coordinated educational programs and technical assistance.

Members have worked together to design regional educational programming including Public Service announcements, brochures, a watershed festival and construction/contractor training workshops. The membership uses the LSS website as a resource and location to publish information on individual community stormwater activities as well as other relevant regional activities.

Through the website and the RSPT, regional communities have come together in recognition that watersheds do not stop at municipal or other political borders and that a team effort is more effective and less expensive than many separate efforts. The team approach has proved effective in seeking grant funding and the unique partnership that crosses the state line with Wisconsin offers increased opportunities for expanding the effort to include the entire western Lake Superior basin. The smaller communities have found a way to partner in a more effective program that remains within their financial constraints. The larger communities can benefit in terms of increased funding opportunities for improving their own programs, but also by increasing citizen and governmental awareness of the importance and value of their program, and by learning from the shared experiences of other team members. The partnership has also provided RSPT members with for the ability to provide better training for the region's contractors through regional workshops. Information from the workshops is posted to LSS. The City of Duluth and other community field staff have benefited from training in stream monitoring and laboratory analyses as part of operating and maintaining water quality stations and helping to develop website sections.

Facing the challenge of designing a campaign directed at protection in world that universally talks of restoration, the RSPT team recognized the need for a different type of campaign. It

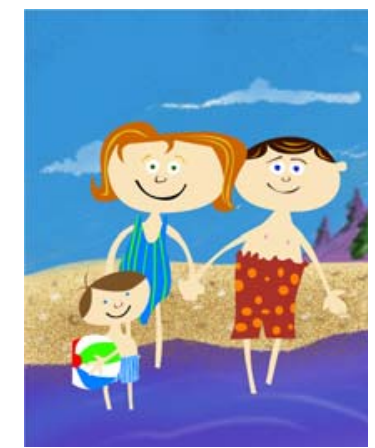
designed a two tiered program that works in tandem with the LSS. The RSPT outreach campaign targets awareness - "It all comes down to your water.” The campaigns consistently stress the link between individual activities and water quality. RSPT elected to use animated characters in public service announcements and brochures, because the pristine nature of the region reduces public sensitivity to attractive natural pictures (www.duluthstreams.org/stormwater/rspt.html ). Cartoon characters include a Lake Superior family, their dog and a fish who illustrate the problems associated with individual behaviors. The campaign has proved popular and informal surveys indicate a high recognition factor. All materials are posted on LSS and include a link to LSS as a source of

additional information.

The second tier of the RSPT campaign is involvement. Individual communities include their activities here. For example, the City of Duluth is using a social marketing approach to change a long-term residential practice of sweeping winter sand and other debris into the street. After completing an initial demonstration project in 2005, the program expanded City wide in 2006. LSS has posted information on the activity and will post the final report including annotated 
descriptions of people's actions and the project's overall effectiveness. The ability to place material on the website saves staff time and guarantees that information goes out - unlike local press outlets that may preempt a press release on an activity at any time. The City of Superior's rain barrel workshop program has also been featured on the website. More local communities are recognizing the value of a resource that they can use to rapidly disseminate a common set of educational material and other information in detail.

\section{CONCLUSION}

Use of the World Wide Web for educational outreach is an excellent approach for regional groups to provide messages to the general public, children and local officials. The site provides educational support for municipalities that want to work together to address watershed concerns more efficiently. Because the Web allows users to work at their own speed, information can be conveyed at many levels. LakeSuperiorStreams.org is a unique website that has taken real-time monitoring data from streams and integrated the data into an information system that provides a resource for school children, college students, teachers, the general public, the private sector and public officials on the impacts of human activity on surface waters. By creating dramatic, but simple and interactive data visualization tools, users can see what is occurring in local streams, compare streams to one another, explore reasons for observed changes in water quality and differences among streams, and find out how individual actions and sound management decisions can reduce impacts on the streams and on Lake Superior. The web approach brings science to the mainstream and increases understanding of links between individual actions and the environment.

\section{ACKNOWLEDGEMENTS}

This project was funded by U.S. Environmental Protection Agency Grant R82932101 (Project \# G1J10127 ) under the Environmental Monitoring for Public Access and Community Tracking (EMPACT) and Science to Achieve Results (STAR) programs to ML and RA. Additional funding support for 2004-06 was granted from the City of Duluth and from Minnesota's Lake Superior Coastal (NOAA Prime) program grants to ML and RA (MLSCP Project No. 306-12-06 and Project No. 306-03-07) and a Pollution Prevention grant from the Minnesota Pollution Control Agency (EPA Prime). We appreciate the help of Carl Richards (MN Sea Grant), Bruce Munson, and Nate Meyer, (Minnesota Extension) for their participation in site development. Substantial in-kind support comes from the City of Duluth, NRRI and Sea Grant at the U. of Minnesota-Duluth, the MPCA, the Western Lake Superior Sanitary District and from the collective efforts of the RSPT members. We particularly acknowledge the help of Mindy Granley (S. St. Louis County Soil \& Water Conservation District) and Erik Larson (U. of Minnesota-Duluth Facilities Management) in creating the Site Design Toolkit; and Jesse Anderson (MPCA) for help with site selection, instrumentation, sampling, analysis, and website review.

\section{REFERENCES}

Anderson, J., M. Evenson, T. Estabrooks, and B. Wilson. 2003. An assessment of representative L. Superior Basin tributaries. MN Pollution Control Agency, St. Paul 55155. 
Axler, R., M.Lonsdale, J.Reed, C.Hagley, J.Schomberg, J.Henneck, G. Host, N.Will, E. Ruzycki, G. Sjerven, C.Richards and B.Munson. 2004. DuluthStreams.org: Community partnerships for understanding urban stormwater and water quality issues at the head of the Great Lakes. NRRI Technical Report NRRI/TR-2004/34, December 2004. Natural Resources Research Institute, University of Minnesota, Duluth, MN 55811.

Axler, R. and M. Lonsdale. 2003. Duluth Streams: Community Partnerships For Understanding Water Quality and Stormwater Impacts at the Head of the Great Lakes (www.duluthstreams.org). Coastline Issue 13.1: 10-15. www.epa.gov/owow/estuaries/coastlines), February 2003.

Host, G. E., N. R. Will, R. P. Axler, C.J. Owen, and B. H. Munson. 2000. Interactive technologies for collecting and visualizing water quality data. Journal of the Urban and Regional Information Systems Association 12:39-45.

MPCA.2004. Minnesota's Impaired Waters and Total Maximum Daily Loads (TMDL):2004 Final List of Impaired Waters (approved by the U.S. EPA on May 13, 2004). www.pca.state.mn.us/water/tmdl/index.html\#tmdl

MPCA. 2000. North Shore land use issues: The real costs of growth. Publication WQ/Lake Superior Basin \#2.03.

Munson, B., R. Huber, R. Axler, G. Host, C. Hagley, C. Moore and G. Merrick. 2003. Investigating water quality through the Internet. The Science Teacher 70(1): 44-49.

Peterson, D. (EPA ed). 2000. Delivering timely water quality information to your community: The Lake Access-Minneapolis project. EPA/625/R-00/012, September 2000, U. S. Environmental Protection Agency, Office of Research and Development, Cincinnati, OH, 45268, USA (contributing authors: R. Axler, J. Barten, J. Goin, C.Hagley, G.Host, B. Liukkonen, B.Munson, B.Peichel, C.Owen, B.Vlach, N.Will). EPA-625/R-00/012, 104 p. 